УДК 373.2.014.6:351.851«19/20»(045)

\author{
Ніколасску Інна Олександрівна \\ доктор педагогічних наук, доцент кафедри дошкільної освіти \\ Черкаський національний університет імені Богдана Хмельницького, м. Черкаси, Україна \\ ORCID 0000-0002-9928-9291X \\ nikolaesky@ukr.net
}

Степанова Наталія Михайлівна

кандидат філософських наук, доцент кафедри професійного розвитку педагогів

КНЗ «Черкаський обласний інститут післядипломної освіти педагогічних працівників

Черкаської обласної ради», м. Черкаси, Україна

ORCID 0000-0002-6842-629X

stepanova76@ukr.net

Соловей Юлія Олександрівна

аспірантка кафедри дошкільної освіти

Черкаський національний університет імені Богдана Хмельницького, м. Черкаси, Україна

ORCID 0000-0003-4778-7640

solovey_yula@ukr.net

\title{
ВПРОВАДЖЕННЯ ДИСТАНЦІЙНОГО СПЕЦКУРСУ «МОНІТОРИНГ ЯКОСТІ ОСВІТИ: ДЕРЖАВНИЙ КОНТРОЛЬ В УПРАВЛІННІ ДІЯЛЬНІСТЮ ЗАКЛАДІВ ДОШКІЛЬНОї ОСВІТИ»
}

\begin{abstract}
Анотація. У статті представлені результати пілотного дослідження щодо формування компетентності студентів закладів вищої освіти та слухачів курсів підвищення кваліфікації при вивченні питань державного контролю в управлінні діяльністю закладів дошкільної освіти в Україні (друга половина XX - початок XXI століття) шляхом упровадження в освітній процес дистанційного спецкурсу «Моніторинг якості освіти: державний контроль в управлінні діяльністю закладів дошкільної освіти». Обгрунтовано актуальність створення й упровадження в освітній процес закладів вищої освіти та закладів післядипломної педагогічної освіти дистанційного спецкурсу. Виділено етапи становлення та розвитку державного контролю в управлінні діяльністю закладів дошкільної освіти України. Враховуючи новітні наукові розвідки 3 цього питання та власні практичні напрацювання, представлено тематичний план спецкурсу. Акцентовано, що результативність упровадження й використання в освітній практиці закладів вищої освіти та закладів післядипломної педагогічної освіти дистанційного спецкурсу залежить від рівня фахової освіти та ІК-компетентності студентів і слухачів. Обгрунтовано судження про те, що в основі впровадження дистанційного спецкурсу лежить принцип початкових знань, який передбачає засвоєння студентами та слухачами опорних знань 3 основ комп'ютерної грамотності, можливість доступу до мережі Інтернет та необхідне технічне забезпечення. За результатами вихідного діагностування студентів 3'ясовано, що впровадження дистанційного спецкурсу сприяє вирішенню фахових завдань, поглибленню знань 3 теорії управління дошкільною освітою, що є базовою основою практичної професійної діяльності, сприяє вирішенню проблем дошкільної освіти сьогодення. Визначено напрями подальшого дослідження: вивчення кращих надбань зарубіжної системи управління системою дошкільної освіти з метою використання та впровадження цього досвіду в систему управління освітою України, використання пропонованого навчально-методичного посібника під час дистанційного навчання при вивченні спецкурсу та розміщення матеріалів на освітній онлайн платформі.
\end{abstract}

Ключові слова: дошкільна освіта; управління; контроль; моніторинг; державний контроль; якість освіти; інформаційно-комунікаційні технології; фахова обізнаність; дистанційний спецкурс. 


\section{1. ВСТУП}

Постановка проблеми. Період дитинства $є$ ключовим у розвитку особистості, адже початкові основи навчання та виховання людина набуває саме в закладі дошкільної освіти, де і проводить перші роки свого життя. Відтак, гостро постає проблема державного контролю над якістю здійснюваної закладами дошкільної освіти освітньої та виховної діяльності, відповідності іï новим вимогам, своєчасного ознайомлення 3 передовим педагогічним досвідом, узагальнення його й поширення в дошкільних установах. Це вимагає актуалізації одного з головних завдань реформування системи освіти України, а саме реалізації основних напрямів державної політики в управлінні дошкільною освітою. Варто зазначити, що ефективність організації контролю в дошкільній освіті є нагальною проблемою, яка набуває особливої актуальності на етапі демократичного розвитку України, а саме започаткування процесу децентралізації, що зумовлено розподілом основних функціональних обов'язків між органами управління освітою [1, с. 12-20], [2, с. 1].

Зауважимо, що особливістю розвитку сучасного суспільства $є$ інформатизація всіх сфер життя, однією з умов якої є інформатизація освіти, яка, на наше переконання, має значний вплив на всі напрямки суспільного розвитку. У результаті зміна парадигми освіти 3 урахуванням сучасного рівня інформатизації та глобальної телекомунікації зосереджується на особистісно орієнтованому навчанні, самостійній та індивідуальній роботі учнів, студентів, слухачів тощо. Це призводить до нового розуміння готовності випускників освітніх закладів до життєвого та професійного рівня діяльності в сучасному інформаційному суспільстві [3, с. 215].

Однією із інноваційних форм неперервної освіти $€$ дистанційне навчання та різноманітні дистанційні авторські спецкурси, що сприяють підвищенню професійного зростання педагогічних працівників [4, с. 251].

Аналіз останніх досліджень і публікацій. Результати аналізу наукової літератури свідчать про те, що питанню державного контролю в управлінні діяльністю закладів дошкільної освіти в Україні (друга половина XX - початок XXI століття) присвячено ряд досліджень. Близькими за темою $€$ наукові праці вітчизняних авторів, у яких розглядаються проблеми, що стосуються таких питань:

- забезпечення ефективних умов організації контролю в дошкільній освіті (B. Божинський [5], В. Гончарук [6], Д. Дзвінчук [7], Г. Касьянов [8], С. Крисюк [9] та інші);

- становлення державного контролю в управлінні діяльністю закладів дошкільної освіти в Україні (А. Гуз [10], Т. Десятов [11], 3. Канівець [12], Т. Куценко [13], А. Панченко [14], Л. Пісоцька [15] та інші);

- сучасний стан проблеми ефективної управлінської діяльності директорів закладів дошкільної освіти (новітні управлінські технології) (Н. Бахмут [16], Т. Богуславська [17], В. Грядуща [18], Г. Дмитренко [19], О. Косенчук [16], I. Крутій [19], Ю. Новгородська [21], Т. Пуденко [17], М. Шевченко [18], А. Яцинік [22]).

У контексті порушеної проблеми наукові доробки зарубіжних учених, присвячені вивченню таких питань: формування кваліфікаційних вимог до дошкільних педагогів для підвищення якості дошкільної освіти (Дж. Денгерінга (J. J. Dengerink), Ф. Каєн (Francesca Caena), М. Когана (M. Cochran), Б. Костера (B. Koster), Р. С. Ньюма (R. S. New) та інші); ефективність технологічної складової професійної підготовки дошкільних педагогів (П. Оберхюмер (P. Oberhumer)); вимір професійної компетентності дошкільного педагога (Соня Шерідан (Sonja Sheridan), Піа Вільямс 
(Pia Williams), Анет Сандберг (Anette Sandberg), Тьюла Вураєн (Tuula Vuorinen)). Вивчення виокремлених напрямів зарубіжних досліджень засвідчило, що предметом аналізу науковців обирався широкий спектр теоретичних і практичних проблем професійної підготовки педагогів у галузі дошкільної освіти, проте поза їх увагою залишалося питання здійснення управління закладами дошкільної освіти на рівні держави, забезпечення інноваційних форм та методів навчання майбутніх вихователів закладів дошкільної освіти.

Незважаючи на значну кількість наукових праць та методичних розробок у дослідженні різних аспектів проблеми, які близькі до нашої розвідки, нами не виявлено навчально-методичного забезпечення у вигляді авторських курсів забезпечення дистанційних форм навчання 3 метою підвищення рівня професійного зростання та розширення кругозору знань педагогічних працівників закладів дошкільної освіти.

Метою статті $\epsilon$ презентація авторського дистанційного спецкурсу для майбутніх вихователів - студентів закладів вищої освіти та слухачів курсів підвищення кваліфікації закладів післядипломної педагогічної освіти «Моніторинг якості освіти: державний контроль в управлінні діяльністю закладів дошкільної освіти», а також аналіз рівня фахової обізнаності майбутніх директорів закладів дошкільної освіти, вихователівметодистів та директорів закладів дошкільної освіти 3 історико-педагогічними матеріалами й питаннями державного контролю в управлінні діяльністю закладів дошкільної освіти в Україні (друга половина XX - початок XXI століття).

\section{2. ТЕОРЕТИЧНІ ОСНОВИ ДОСЛІДЖЕННЯ}

Дошкільна освіта - фундамент, на якому базується вся подальша освіта. Таке закономірне правило варто враховувати у своїй роботі як колективу закладу дошкільної освіти, так і владним структурам державного управління (Л. Пісоцька) [2]. У Законі України «Про дошкільну освіту» зазначено, що заклад дошкільної освіти має забезпечувати реалізацію права дитини на здобуття дошкільної освіти, іiї фізичний, розумовий і духовний розвиток, соціальну адаптацію та готовність продовжувати освіту [23, с. 49].

Науковці О. Кононко [24, с. 14] та А. Зайченко [24, с. 14] зауважують, що заклад дошкільної освіти як соціальний інститут повинен:

- задовольняти потреби громадян відповідної території у здобутті дошкільної освіти;

- забезпечувати відповідність рівня дошкільної освіти вимогам Базового компонента дошкільної освіти;

- створювати безпечні та нешкідливі умови розвитку, виховання й навчання дітей, режим роботи, умови для фізичного розвитку та зміцнення здоров'я відповідно до санітарно-гігієнічних вимог та забезпечувати їх дотримання;

- формувати в дітей гігієнічні навички й основи здорового способу життя, норми безпечної поведінки;

- зберігати та зміцнювати здоров'я дітей;

- здійснювати соціально-педагогічний патронат, взаємодіяти з сім'єю;

- бути осередком поширення серед батьків психолого-педагогічних і фізіологічних знань про дітей дошкільного віку; 
- додержуватися фінансової дисципліни, зберігати матеріально-технічну базу; здійснювати інші повноваження відповідно до статуту закладу дошкільної освіти [24, c. 14].

Відповідно загальні вимоги, які ставляться до закладів дошкільної освіти, відображені в нормативно-правових документах органів управління та регламентуються нормативно-правовими документами дошкільної установи (Закони України «Про освіту», «Про дошкільну освіту»; нормативно правові акти «Національна стратегія розвитку освіти в Україні на період до 2021 року», «Положення про дошкільний навчальний заклад затверджене постановою Кабінету Міністрів України від 12 березня 2003 р. №305», «Про затвердження Нормативів наповнюваності груп закладів дошкільної освіти (ясел-садків) компенсуючого типу, класів спеціальних загальноосвітніх шкіл (шкіл-інтернатів), груп подовженого дня і виховних груп загальноосвітніх навчальних закладів усіх типів та порядку поділу класів на групи при вивчені окремих предметів загальноосвітніх навчальних закладах, «Типовий перелік обов'язкового обладнання, навчально-наочних посібників та іграшок в дошкільних навчальних закладах, затверджений наказом Міністерства освіти України від 11 вересня 2002 р. №509», «Планування роботи в дошкільних навчальних закладах (лист Міністерства освіти і науки України від 03.07.2009 p. №1/9-455)» та інші), Наказ МОН України «Про затвердження порядку проведення моніторингу якості освіти» (№ 54 від 16.01.2020) [10, с. 10], [33].

Результати аналізу наукової літератури та інформативних джерел свідчать про те, що термін «управління» розглядається як елемент і функція організованої системи, що забезпечує збереження певної структури, підтримання режиму діяльності, реалізацію програми та запланованої мети [25, с. 674].

Дослідник М. Поташник [20] звертає увагу на те, що управління $є$ планомірною роботою всіх суб'єктів, яка має забезпечувати становлення, стабілізацію, оптимальне функціонування та обов'язково розвиток дошкільної установи [20]. Натомість, державне управління освітою трактується як цілеспрямований процес, що пов'язаний 3 розробленням, прийняттям та впровадженням у практичну діяльність закладів освіти i органів державного управління рішень, які спрямовані на реалізацію політики забезпечення якості освіти та задоволення потреб ринку праці на міжнародному, національному, регіональному і місцевому рівнях [15, с. 8], [26, с. 110]

Ми вважаємо, що управління - це невід’ємна соціальна функція (діяльність), що існує на рівні соціальних інститутів, груп, класів та здійснюється в інтересах того чи іншого закладу задля досягнення поставленої мети, цілей та завдань.

На нашу думку, державне управління в освіті - це складна структурна ієрархічна система, що регулюється нормами законодавчих актів України, та важлива ланка у здійсненні систематичного контролю за діяльністю закладів освіти чи інших освітніх організацій. Це стосується й галузі дошкільної освіти. У Законах України «Про освіту», «Про дошкільну освіту», «Про основні засади державного нагляду (контролю) у сфері господарської діяльності», наказах Міністерства «Про затвердження Порядку державної атестації дошкільних, загальноосвітніх, позашкільних навчальних закладів», «Про затвердження «Примірного положення про порядок звітування керівників дошкільних, загальноосвітніх та професійно-технічних навчальних закладів перед педагогічним колективом та громадськістю», «Інструкції про ділову документацію в дошкільних закладах»; Положенні про дошкільний навчальний заклад зазначено про функції контролю. Водночас цей процес $є$ елементом зворотного зв'язку, що дає змогу своєчасно відреагувати на будь-які зміни чи відхилення від запланованого шляху досягнення 
поставлених цілей розвитку закладів дошкільної освіти. [14, с. 9]. Тобто контроль - це не просто процес перевірки, а й зіставлення фактичних результатів із запланованими або встановленими стандартами для можливого коригування задля усунення недоліків чи отримання якісних показників [27, с. 135], [28, с. 132].

Дослідниця Т. Маматова пропонує розглядати поняття «державний контроль» як реалізацію функцій втручання держави в діяльність закладів будь-яких сфер діяльності в разі виникнення загрози безпеці, процес вироблення коригувальних дій, що базується на порівнянні фактичного та заявленого стану об'єкта відповідно до визначених критеріїв [29, c. 23-26]. Ми суголосні з таким визначенням, адже головне - не вказати на недоліки, а вчасно їх виправити, а по можливості, попередити на початкових етапах.

Державний контроль в управлінні діяльністю закладів дошкільної освіти в Україні здійснюють Міністерство освіти і науки України, інші центральні органи виконавчої влади, яким підпорядковані заклади дошкільної освіти, Державна інспекція навчальних закладів, обласні, Київська міська державна адміністрація, районні державні адміністрації та підпорядковані їм органи управління освітою, органи місцевого самоврядування [30, с. 17-18].

Для детального вивчення питання державного контролю в управлінні діяльністю закладів дошкільної освіти України ми звернемося до історичної ретроспективи.

Дослідивши наукові джерела із зазначеної теми, ми виділили етапи становлення та розвитку державного контролю в управлінні діяльністю закладів дошкільної освіти України:

I етап (1943-1959 рр.) - відбудова системи дошкільної освіти (1943р.), розширення мережі дитячих закладів і поліпшення їх матеріально-технічної бази (1945р.), оновлення навчальних програм для дітей дошкільного віку (1959р.).

II етап (1960-1969 рр.) - становлення системи громадського огляду дошкільних закладів України (зародження державного контролю за діяльністю закладів дошкільної освіти (1960р.), розроблення перших нормативно-правових документів, що регламентують діяльність Міністерства освіти СРСР з управління й контролю за дошкільними установами (1969р.)).

III етап (1970-1989 pр.) - розширення мережі дитячих садків, поступове розв'язання проблем із кількістю дошкільних закладів (реорганізація дошкільних установ (1970р.), отримання прав відділами народної освіти контролювати діяльність закладів дошкільної освіти (1978-1979 рр.), упровадження положення про інспектора-методиста 3 дошкільного виховання (1980р.), підвищення рівня розвитку державного контролю в управлінні діяльністю закладів дошкільної освіти (1989р.).

IV етап (1990-2000 pp.) - кризовий стан і занепад розвитку системи державного контролю в управлінні діяльністю закладів дошкільної освіти (1990-1992р.), пошук нових управлінських підходів (1993-2000 рр.).

Окремо ми виділили етапи розвитку державного контролю початку XXI століття:

I етап (2001-2002 рр.) - відродження дошкільної освіти як такої, що має свої права та обов'язки, зародження безпосереднього державного контролю в управлінні діяльністю закладів дошкільної освіти різних типів і форм власності (затверджено наказ про порядок державної атестації закладів дошкільної освіти);

II етап (2003-2009 рр.) - етап посиленої уваги до розвитку управління в галузі дошкільної освіти;

III етап (від 2010 р. до наших днів) - етап оптимізації, узагальнення, пошуку нових ідей, посилення розвитку системи управління та державно-громадського контролю за закладами дошкільної освіти.

Отож, варто зауважити, що система розвитку державного контролю в управлінні діяльністю закладів дошкільної освіти другої половини XX - початку XXI століття має 
обгрунтовані історичні закономірності. Українське суспільство за визначений нами період перейшло з однієї країни в іншу, із Радянського Союзу в незалежну Україну. Зміна політична не залишила без змін устої життя, економічні зв'язки, навіть суспільні цінності. Зміни торкнулись усіх сфер життя, зокрема освіти. Змінюючись, перебудовуючись, запроваджуючи нові демократичні підходи, державний контроль в управлінні діяльністю закладів дошкільної освіти України у своєму розвитку пройшов ряд випробувань і на початку XXI століття утвердився як закономірна невід'ємна одиниця освітнього процесу, яка є важливою ланкою в управлінні діяльністю дошкільних установ держави [31, с. 51-52].

\section{3. РЕЗУЛЬТАТИ ДОСЛІДЖЕННЯ}

Для підвищення рівня професійного зростання та фахової компетентності майбутніх керівників закладів дошкільної освіти та директорів закладів дошкільної освіти 3 досліджуваного питання нами було розроблено дистанційний спецкурс.

Дистанційний спецкурс «Моніторинг якості освіти: державний контроль в управлінні діяльністю закладів дошкільної освіти» надає можливість майбутнім керівникам закладів дошкільної освіти (студентам закладів вищої освіти за означеною спеціальністю) та слухачам закладів післядипломної педагогічної освіти (директори закладів дошкільної освіти, вихователі-методисти) без відриву від основного виду діяльності ознайомитися 3 теоретичними основами здійснення моніторингу якості дошкільної освіти, історикопедагогічними матеріалами впровадження державного контрою в управлінні закладами дошкільної освіти України та підвищити власний рівень професійної компетентності.

Основою результативності впровадження дистанційного спецкурсу $є$ принцип початкових знань, який передбачає засвоєння студентами та слухачами опорних знань 3 основ комп’ютерної грамотності, можливість доступу до мережі Інтернет та необхідне технічне забезпечення, а також вивчення насамперед вихідних положень, провідних ідей 3 означеної теми. Застосування принципу початкових знань дозволить повторно осмислювати вивчений раніше матеріал із застосуванням ІК-технологій, що забезпечить використання сформованих знань на практиці.

Упровадження дистанційного спецкурсу, на наше переконання, сприятиме вирішенню фахових завдань, поглибленню знань з теорії управління дошкільною освітою, що є базовою основою практичної професійної діяльності, i врешті сприятиме вирішенню проблем дошкільної освіти сьогодення. Основою розробки дистанційного спецкурсу стала ідея поєднати теоретичні, професійно-діяльнісні завдання і методики самопізнання, самоосвіти та саморозвитку. Відповідно до цього пропонований дистанційний спецкурс містить два взаємопов'язані модулі, які завершуються контрольним тестуванням [4, с. 252].

Табличя 1.

Тематичний план дистанційного спецкурсу «Моніторинг якості освіти: державний контроль в управлінні діяльністю закладів дошкільної освіти»

\begin{tabular}{|l|c|}
\hline \multicolumn{1}{|c|}{ Назви змістових модулів і тем } & $\begin{array}{c}\text { Кількість } \\
\text { годин / } \\
\text { кредити ЕСТS }\end{array}$ \\
\hline \multicolumn{2}{|c|}{ Змістовий модуль I. Загальні основи моніторингу якості освіти } \\
\hline Тема 1.1. Якість освітнього процесу як загальна наукова проблема \\
Практичне заняття 1. Якість освітнього процесу як загальна наукова проблема \\
Тема 1.2. Становлення та розвиток моніторингу якості освіти & 2 \\
Практичне заняття 2. Становлення та розвиток моніторингу якості освіти & 2 \\
\hline
\end{tabular}




\begin{tabular}{|l|c|}
\hline $\begin{array}{l}\text { Тема 1.3. Контроль у системі якості освіти } \\
\text { Практичне заняття 3. Контроль у системі якості освіти }\end{array}$ & \multicolumn{1}{c|}{2} \\
\hline Всього годин / кредитів на модуль & $\begin{array}{c}\mathbf{1 2} \text { год /0,4 } \\
\text { кредиту }\end{array}$ \\
\hline \multicolumn{1}{|c|}{ 3містовиц̆ модуль ІІ. Організація й проведення освітнього моніторингу дошкільної освіти } \\
\hline $\begin{array}{l}\text { Тема 2.1. Організації та проведення моніторингу в освітньому процесі } \\
\text { Практичне заняття 4. Організація та проведення моніторингу в освітньому процесі }\end{array}$ \\
\hline $\begin{array}{l}\text { Тема 2.2. Державний контроль в управлінні діяльністю закладів дошкільної освіти } \\
\text { Практичне заняття 5. Державний контроль в управлінні діяльністю закладів дошкільної } \\
\text { освіти } \\
\text { Навчальний практикум. Особливості міжвідомчого контролю в закладах дошкільної освіти } \\
\text { (співпраця з пожежною та санітарною інспекціями) }\end{array}$ \\
\hline Підсумковий тест-контроль. & 2 \\
\hline Всього годин / кредитів на модуль & 2 \\
\hline Всього годин / кредити & $\begin{array}{c}\mathbf{1 2} \text { год /0,4 } \\
\text { кредиту }\end{array}$ \\
\hline
\end{tabular}

Як свідчить власний практичний досвід та викладацька діяльність у сфері вищої освіти, найбільш функціональним і поширеним ресурсом для повноцінного користування дистанційним спецкурсом $є$ розроблена науково-педагогічними працівниками кафедри дошкільної освіти Черкаського національного університету імені Богдана Хмельницького онлайн платформа «Дошкільн+Я» (http://doshkilly.at.ua).

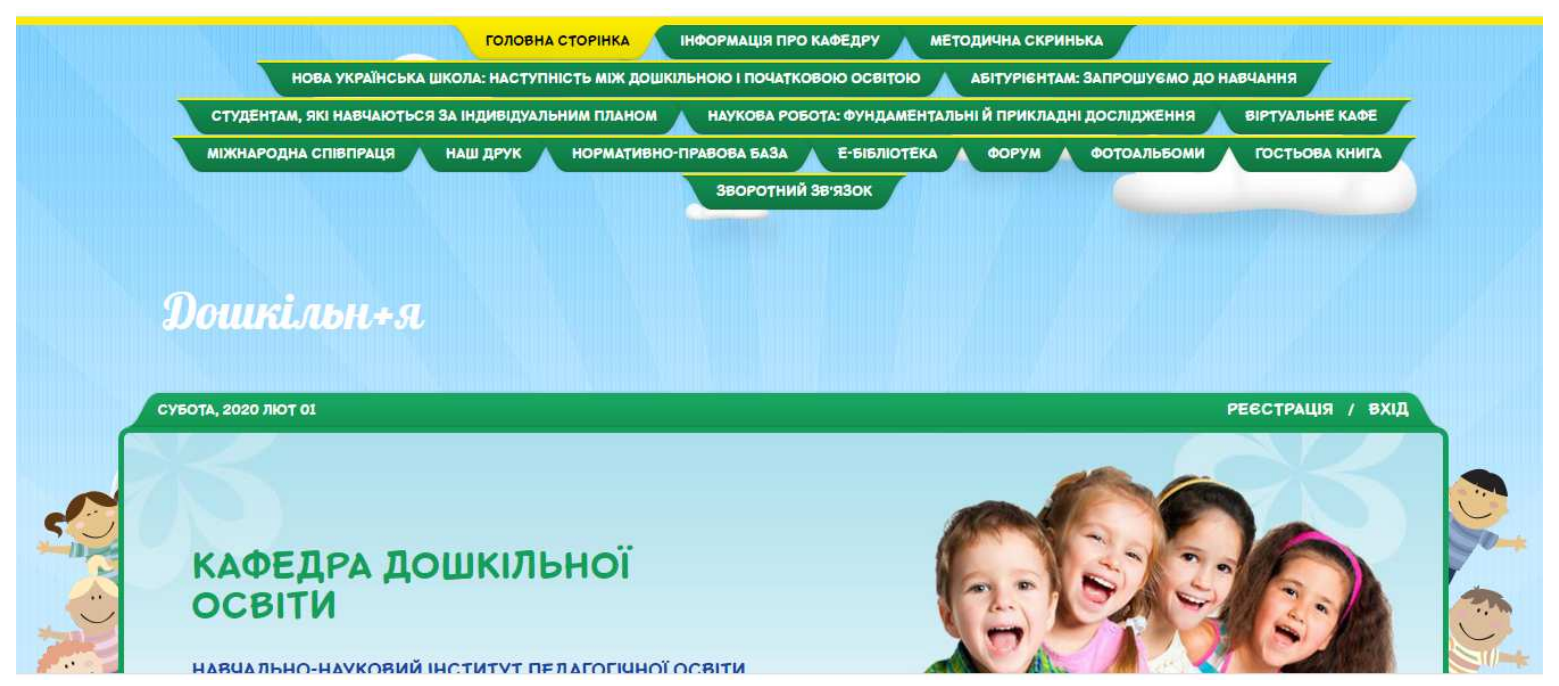

\section{Рис.1. Онлайн платформа «Дошкільн+Я»}

Цей ресурс як віртуальна форма науково-методичної роботи кафедри є своєрідним накопичувальним освітньо-інформаційним центром освітнього середовища кафедри дошкільної освіти, який спрямований на спілкування учасників освітнього процесу: студент - викладач - освітянська спільнота. Існуючі рубрики на платформі (наприклад, «Методична скринька», «Студентам, які навчаються за індивідуальною формою навчання», «Віртуальне кафе», «Е-бібліотека» та інші), першочергово, пов'язані 3 навчанням студентів, його якістю й відповідно результатом цієї якості та забезпечують 
підвищення рівня знаннєвої обізнаності, фахової компетентності й педагогічної майстерності майбутніх педагогів дошкільної галузі.

Розглядаючи дистанційне та очно-дистанційне навчання як дієву форму отримання відповідних фахових знань, пропонований нами для вивчення дистанційний спецкурс «Моніторинг якості освіти: державний контроль в управлінні діяльністю закладів дошкільної освіти» розміщено в рубриці «Наукова робота: фундаментальні й прикладні дослідження» (http://doshkilly.at.ua/index/upravlinnja_v_doshkilnij_osviti/0-31) та передбачає надання можливості студентам та слухачам курсів підвищення кваліфікації ознайомитися 3 теоретичним матеріалом, який містить методичні кейси 3 переліком рекомендованої літератури до тем та посилання на е-ресурси в мережі Інтернет.

Dountivblitst

«МОНТТОРИНГ ЯКОСТІ ОСВІТИ: ДЕРЖАВНИЙ КОНТРОЛЬ В УПРАВЛННН ДІЯЛЬНІСТЮ ЗАК.ААДІВ ДОШКІЛЬНОӤ ОСВІТИ,

Потреба покрашення якості дошкільної освіти не зникає протягом багатьох років, тож на ній завжди акцентують особливу увагу. Гостро постає проббема державного контролю над якістю здійснюваної акцентують особливу увагу. Гостро постає пробтема державного контролю над якістю здійснюваноі виявлення, узагальнення й поширення передового педагогічного досвіду.

Дієвою системою досліджень, яка дозволяє визначити якість освіти є.моніторинг.

Головною метою моніторингу $\epsilon$ відстеження динаміки якості освітніх послуг, шо надаються освітнім закладом, та ефективність управтіння якістю освітн.

об̆’єктам моніторингу є зміст освіти та засоби, що забезпечують освітній процес, різноманітні види діяльності людини, окремі компоненти системи освіти, освітній процес, його етапи та результати

Преометом моніторинуу є якість освіти, як головннй критерій забезпечення освітньої діяльності закладу.

Моніторинг у системі доикільної освіти - це спеціально організоване, цільове, систематнчне

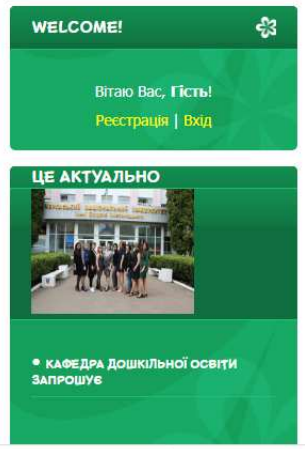

Рис.2. Дистаниійний спецฺкурс «Моніторинг якості освіти: державний контроль в управлінні діяльністю закладів дошкільної освіти»

На основі інтеграції даних філософської, психологічної та педагогічної літератури 3 навчання у вищій школі, а також зібраний і проаналізований фактичний матеріал спецкурсу дозволяе проілюструвати теоретичний матеріал контентним доповненням у вигляді відеоматеріалу («Управління освітою. Які е-рішення зроблять менеджмент ефективнішим» (https://www.youtube.com/watch?v=SCniaYY7yq8); «Законодавство України у сфері дошкільної освіти» (https://www.youtube.com/watch?v=kq2Dj4Zbz6Y); «Публічна консультація «Якісна д доступна дошкільна освіта» (https://www.youtube.com/watch?v=KRJJ-cFX0C0) та інші відеоматеріали). Пропоновані відео слугують додатковим ресурсом отримання й закріплення існуючих знань та вироблення практичних умінь і навичок у професійній діяльності.

Для встановлення рівня обізнаності майбутніх керівників закладів дошкільної освіти (студенти закладів вищої освіти) та слухачів закладів післядипломної педагогічної освіти (директори закладів дошкільної освіти, вихователі-методисти) 3 проблемою державного контролю в управлінні діяльністю закладів дошкільної освіти України ми використали анкети-опитування, підготовлені у Google Forms (http://doshkilly.at.ua/natural/slukhachi_kursiv_pidvishhennja_kvalifikacii-vikhov.pdf; http://doshkilly.at.ua/natural/os_bakalavr.pdf; http://doshkilly.at.ua/natural/os_magistr.pdf;), які складалися з двох блоків запитань. Запитання сформульовані у вигляді тверджень, до яких респондент пропонує власне судження. При цьому застосовано чотирьохальтернативний 
набір можливих відповідей: «достатньо володію інформацією», «не достатньо володію інформацією», «не володію інформацією взагалі», «можу поділитися матеріалами 3 даного питання».

Протягом 2017-2019 навчальних років у пілотному дослідженні взяли участь 373 респонденти Черкаського національного університету імені Богдана Хмельницького, КНЗ «Черкаський обласний інститут післядипломної освіти педагогічних працівників Черкаської обласної ради», комунального вищого навчального закладу «Херсонська академія неперервної освіти» Херсонської обласної ради, Прикарпатського національного університету імені Василя Стефаника. Із них - 31 студент (4 курс) спеціальності 012 «Дошкільна освіта» освітнього ступеня «бакалавр»; 3-поміж студентів другого магістерського рівня вищої освіти на здобуття ступеня «магістр» спеціальності 012 «Дошкільна освіта» залучено до проведення експерименту 297 респондентів; виявили цікавість до теми нашого дослідження 45 слухачів курсів підвищення кваліфікації (21 вихователь закладів дошкільної освіти; 11 вихователів-методистів; 13 директорів закладів дошкільної освіти).

Метою аналітико-синтетичного (констатувального) етапу експерименту дослідження було отримання оперативної інформації про реальний стан досліджуваної проблеми в закладах вищої та післядипломної педагогічної освіти, які становили експериментальні майданчики дослідження; проведення анкетування 3 метою виявлення готовності майбутніх вихователів та педагогів до фахового самовдосконалення в умовах упровадження дистанційного навчання; розроблення та впровадження в освітній процес експериментальних майданчиків - закладів освіти дистанційного спецкурсу «Моніторинг якості освіти: державний контроль в управлінні діяльністю закладів дошкільної освіти»; аналіз результатів дослідження та прогностика подальшого вивчення проблеми.

Аналіз отриманих даних про стан обізнаності студентами спеціальності 012 «Дошкільна освіта», які здобувають освітній ступень «бакалавр» 3 інформацією про проблему державного контролю в управлінні діяльністю закладів дошкільної освіти в Україні (друга половина XX - початок XXI століття), усвідомлення іiі актуальності на момент опитування свідчать про те, що (I блок запитань): 1) більш ніж 75,0 \% респондентів розуміють сутність поняття «управління», але не можуть дати конкретного визначення цього терміну. На нашу думку, це пояснюється браком дисциплін управлінського циклу; 2) $55,5 \%$ респондентів вказують на достатнє володіння інформацією про поняття «контроль»; 3) найменш відомим (23,0%) для студентів виявилось питання поняття «державний контроль» та форми державного контролю в управлінні діяльністю закладів дошкільної освіти; 4) труднощі викликало питання про інституційний аудит: 82,11 \% студентів вказали, що не розуміють даного поняття.

Наведені результати опитування свідчать про те, що студенти першого (бакалаврського) ступеня спеціальності 012 «Дошкільна освіта» мають труднощі та мало поінформовані в питаннях управлінського характеру в галузі дошкільної освіти.

Вважаємо доречним уточнити, що інституційний аудит - це зовнішнє оцінювання діяльності закладів загальної середньої освіти, що базується на грунтовному вивченні освітніх та управлінських процесів. Відповідно до Наказу МОН України «Про затвердження Порядку проведення інституційного аудиту закладів загальної середньої освіти» (Наказ від 09.01.2019 № 17) «основною функцією інституційного аудиту $\epsilon$ оцінювання якості освітньої діяльності закладу освіти та вироблення рекомендацій щодо: підвищення якості освітньої діяльності та вдосконалення внутрішньої системи 
забезпечення якості освіти; приведення освітнього та управлінського процесів у відповідність до вимог законодавства» [32].

Наступний блок запитань містив перелік тем з дистанційного спецкурсу «Моніторинг якості освіти: державний контроль в управлінні діяльністю закладів дошкільної освіти», де студенти мали вказати наскільки вони обізнані в тій чи іншій темі («достатньо володію інформацією», «не достатньо володію інформацією», «не володію інформацією взагалі», «можу поділитися матеріалами 3 даного питання») до опрацювання дистанційного спецкурсу та після його опрацювання. Результати даних щодо рівня обізнаності студенів першого (бакалаврського) ступеня спеціальності 012 «Дошкільна освіта» до та після опрацювання дистанційного спецкурсу «Моніторинг якості освіти: державний контроль в управлінні діяльністю закладів дошкільної освіти» представлені на рисунку 3 та на рисунку 4.

Наведені результати опитування до опрацювання дистанційного спецкурсу «Моніторинг якості освіти: державний контроль в управлінні діяльністю закладів дошкільної освіти» свідчать про те, що найбільше труднощів студенти першого (бакалаврського) ступеня спеціальності 012 «Дошкільна освіта» мають щодо розкриття таких питань: становлення та розвиток моніторингу якості дошкільної освіти (не володіли інформацією взагалі - 67,74 \%), організація контролю в закладі дошкільної освіти (не володіли інформацією взагалі - 64,52\%), державний контроль в управлінні діяльністю закладів дошкільної освіти (не володіли інформацією взагалі - 83,87 \%), інституційний аудит закладів освіти (не володіли інформацією взагалі - 93,55\%), методи державного контролю в управлінні діяльністю закладів дошкільної освіти (не володіли інформацією взагалі - 93,55 \%).

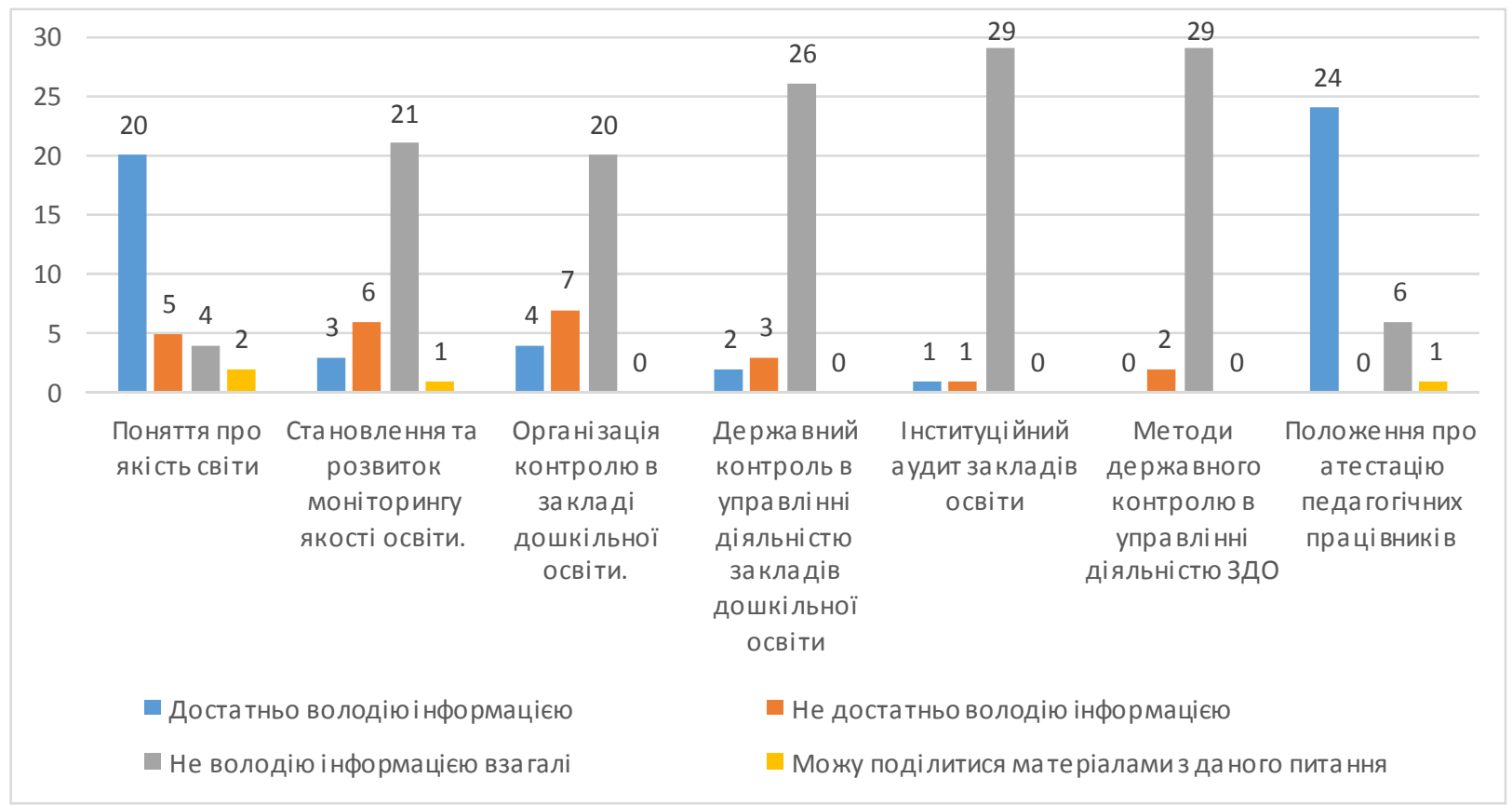

Рис. 3. Результати обізнаності студентів спеціальності 012 «Дошкільна освіта» освітнього ступеня «бакалавр» з проблемою державного контролю в управлінні діяльністю закладів дошкільної освіти України (друга половина XX - початок XXI століття) (до опраџювання дистанщійного спецкурсу «Моніторинг якості освіти: 
державний контроль в управлінні діяльністю закладів домкільної освіти» (за темами дистанційного спеикурсу))

Після опрацювання дистанційного спецкурсу «Моніторинг якості освіти: державний контроль в управлінні діяльністю закладів дошкільної освіти» студенти першого (бакалаврського) ступеня спеціальності 012 «Дошкільна освіта» покращили свої знання 3 тем, які потребували, на їхню думку, детального вивчення, а саме: 1) 74,19 \% студентів достатньо оволоділи питанням становлення та розвитку моніторингу якості дошкільної освіти, а 16,13 \% готові поділитися матеріалом з даного питання; 2) 90,32 \% респондентів достатньо оволоділи інформацією щодо організації контролю в закладі дошкільної освіти, а 6,45 \% засвідчили готовність поділитися матеріалом; 3) 87,10\% респондентів вказують на достатнє оволодіння інформацією про державний контроль в управлінні діяльністю закладів дошкільної освіти, 6,45 \% студентів готові поділитися матеріалом; 4) 93,55 \% респондентів достатньо володіють інформацією про інституційний аудит закладів освіти, а поділитися матеріалом у змозі $6,45 \%$; 5) $87,10 \%$ опитаних достатньо оволоділи питанням методів державного контролю в управлінні діяльністю закладів дошкільної освіти, а поділитися матеріалами 3 даного питання можуть 9,68 \% студентів.

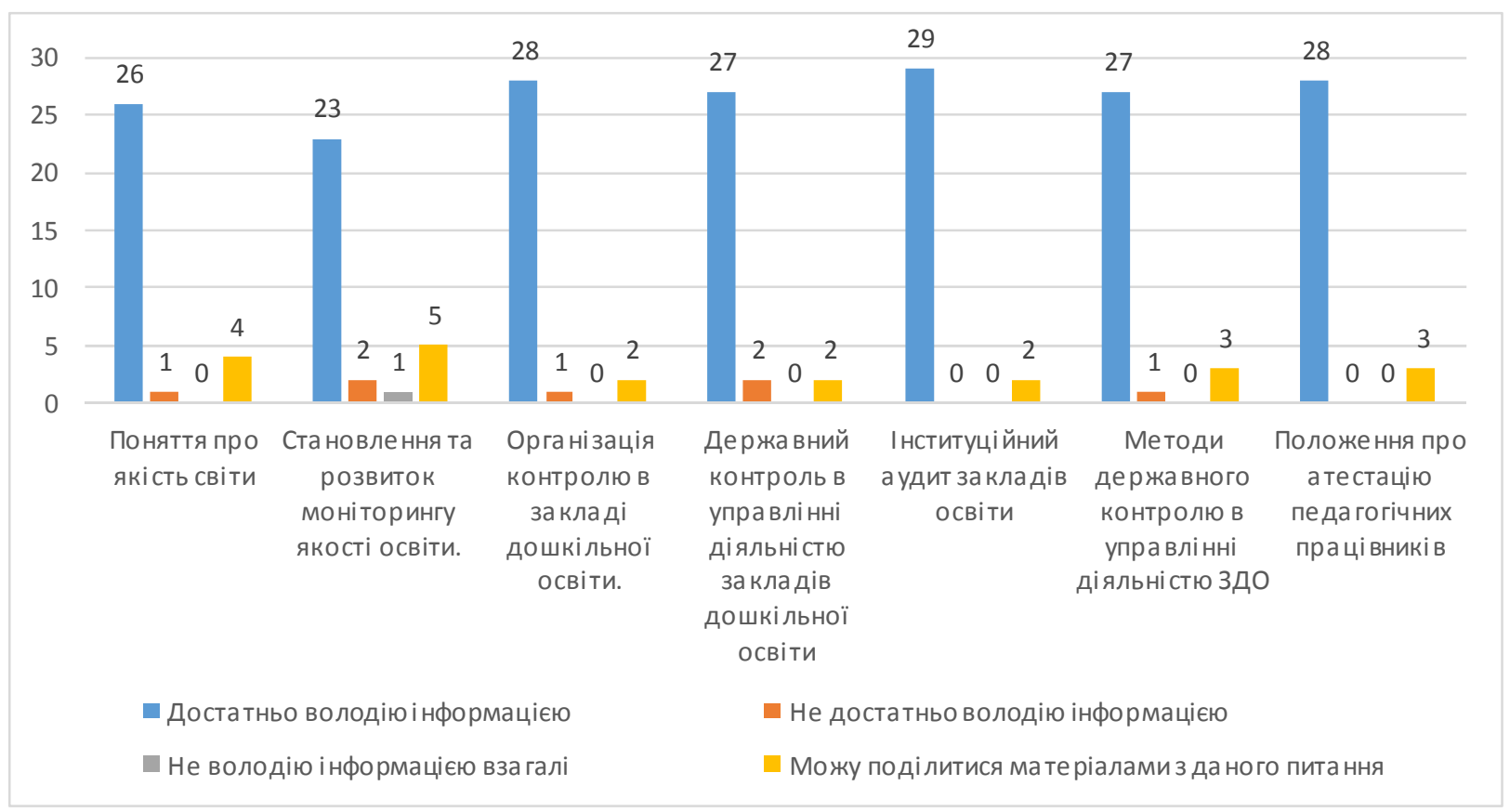

Рис. 4. Результати обізнаності студентів спеціальності 012 «Дошкільна освіта» освітнього ступеня «бакалавр» з проблемою державного контролю в управлінні діяльністю закладів дошкільної освіти України (друга половина XX - початок XXI століття) (після опраџювання дистанційного спецкурсу «Моніторинг якості освіти: державний контроль в управлінні діяльністю закладів дошкільної освіти» (за темами дистаниійного спеиякурсу))

Варто зазначити, що розробка та впровадження дистанційного спецкурсу «Моніторинг якості освіти: державний контроль в управлінні діяльністю закладів 
дошкільної освіти» в освітній процес закладів вищої освіти для студентів першого (бакалаврського) ступеня спеціальності 012 «Дошкільна освіта» виявилася дієвою та ефективною, адже, на нашу думку, студенти здобули знання, які необхідні їм у майбутній практичній професійній діяльності. Для покращення рівня обізнаності студентів першого (бакалаврського) ступеня спеціальності 012 «Дошкільна освіта» 3 питань управління дошкільною освітою варто було $б$ у навчально-методичний комплекс дисциплін «Дошкільна педагогіка» та «Історія дошкільної педагогіки» додати наступні теми: «Історіографія становлення державного контролю за діяльністю закладів дошкільної освіти України (друга половина XX - початок XXI століття», «Становлення та розвиток моніторингу якості освіти», «Організація контролю в закладі дошкільної освіти».

Аналіз отриманих даних про стан обізнаності студентами спеціальності 012 «Дошкільна освіта», які здобувають освітній ступень «магістр», з інформацією про проблему державного контролю в управлінні діяльністю закладів дошкільної освіти в Україні (друга половина XX - початок XXI століття), усвідомлення іiі актуальності на момент опитування свідчать про те, що (I блок запитань): 1) більш ніж 89,0 \% респондентів розуміють сутність поняття «управління» та можуть дати конкретне визначення даному поняттю; 2) результати 79,76 \% респондентів вказують на достатне володіння інформацією про поняття «контроль»; 3) порівняно зі студентами першого (бакалаврського) ступеня спеціальності 012 «Дошкільна освіта» (23,0\%), студенти, які здобувають освітній ступень «магістр», краще усвідомлюють та розуміють питання «державного контролю» та форм державного контролю в управлінні діяльністю закладів дошкільної освіти $(38,0$ \% респондентів); 4) як і в студентів першого (бакалаврського) ступеня, так і студентів-магістрантів труднощі викликало питання про інституційний аудит, адже 77,0 \% студентів вказали, що не розуміють даного поняття.

Наведені результати опитування свідчать про те, що студенти спеціальності 012 «Дошкільна освіта», які здобувають освітній ступень «магістр», мають труднощі та потребують додаткової інформації в питаннях управлінського характеру в галузі дошкільної освіти.

Наступний блок запитань містив перелік тем з дистанційного спецкурсу «Моніторинг якості освіти: державний контроль в управлінні діяльністю закладів дошкільної освіти», де студенти мали вказати наскільки вони обізнані 3 тією чи іншою темою («достатньо володію інформацією», «не достатньо володію інформацією», «не володію інформацією взагалі», «можу поділитися матеріалами з даного питання) до опрацювання дистанційного спецкурсу та після його опрацювання. Результати даних щодо виявлення обізнаності студенів спеціальності 012 «Дошкільна освіта», які здобувають освітній ступень «магістр» до та після опрацювання дистанційного спецкурсу «Моніторинг якості освіти: державний контроль в управлінні діяльністю закладів дошкільної освіти» презентовані у зведеній таблиці 2.

Таблиця 2.

\author{
Результати обізнаності студентів спеціальності 012 \\ «Дошкільна освіта» освітнього ступеня «магістр» 3 проблемою державного контролю \\ в управлінні діяльністю закладів дошкільної освіти України \\ (друга половина XX - початок XXI століття) \\ (за темами дистанційного спецкурсу)
}




\begin{tabular}{|c|c|c|c|c|c|c|c|c|c|c|c|c|}
\hline \multirow[b]{2}{*}{ Питання } & \multicolumn{3}{|c|}{$\begin{array}{c}\text { Достатньо володію } \\
\text { інформацією }\end{array}$} & \multicolumn{3}{|c|}{$\begin{array}{c}\text { Не володію } \\
\text { інформацією } \\
\text { взагалі }\end{array}$} & \multicolumn{3}{|c|}{$\begin{array}{c}\text { Не достатньо } \\
\text { володію } \\
\text { інформацісю }\end{array}$} & \multicolumn{3}{|c|}{$\begin{array}{c}\text { Готовий } \\
\text { поділитися } \\
\text { матеріалом }\end{array}$} \\
\hline & 움 & 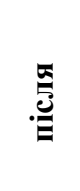 & 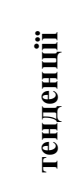 & 是 & . & 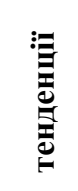 & $\stackrel{?}{\square}$ & 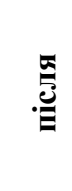 & 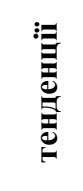 & 움 & 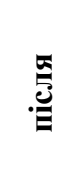 & 焉 \\
\hline $\begin{array}{l}\text { Поняття про } \\
\text { якість освіти }\end{array}$ & $\begin{array}{c}257 \\
86,5 \\
3 \% \\
\end{array}$ & $\begin{array}{c}281 \\
94,6 \\
1 \% \\
\end{array}$ & $\begin{array}{c}+24 \\
8,08 \\
\%\end{array}$ & $\begin{array}{c}14 \\
4,71 \\
\%\end{array}$ & 0 & $\begin{array}{c}-14 \\
4,71 \\
\%\end{array}$ & $\begin{array}{c}11 \\
3,70 \\
\%\end{array}$ & 0 & $\begin{array}{c}-11 \\
3,70 \\
\%\end{array}$ & $\begin{array}{c}15 \\
5,05 \\
\%\end{array}$ & $\begin{array}{c}16 \\
5,39 \\
\%\end{array}$ & $\begin{array}{c}+1 \\
0,34 \\
\%\end{array}$ \\
\hline $\begin{array}{c}\text { Становлення та } \\
\text { розвиток } \\
\text { моніторингу якості } \\
\text { освіти }\end{array}$ & $\begin{array}{c}156 \\
52,5 \\
3 \%\end{array}$ & $\begin{array}{l}289 \\
97,3 \\
1 \%\end{array}$ & $\begin{array}{r}+133 \\
44,7 \\
8 \%\end{array}$ & $\begin{array}{c}71 \\
23,9 \\
1 \%\end{array}$ & 0 & $\begin{array}{c}-71 \\
23,9 \\
1 \%\end{array}$ & $\begin{array}{c}67 \\
22,5 \\
6 \%\end{array}$ & 0 & $\begin{array}{l}-67 \\
22,5 \\
6 \%\end{array}$ & $\begin{array}{c}3 \\
1,01 \\
\%\end{array}$ & $\begin{array}{c}8 \\
2,69 \\
\%\end{array}$ & $\begin{array}{c}+5 \\
1,68 \\
\%\end{array}$ \\
\hline $\begin{array}{c}\text { Організація } \\
\text { контролю в } \\
\text { закладі дошкільної } \\
\text { освіти }\end{array}$ & $\begin{array}{c}99 \\
33,3 \\
3 \%\end{array}$ & $\begin{array}{l}291 \\
97,9 \\
8 \%\end{array}$ & $\begin{array}{r}+192 \\
64,6 \\
5 \%\end{array}$ & $\begin{array}{c}63 \\
21,2 \\
1 \%\end{array}$ & 0 & $\begin{array}{c}-63 \\
21,2 \\
1 \%\end{array}$ & $\begin{array}{l}135 \\
45,4 \\
5 \%\end{array}$ & 0 & $\begin{array}{r}-135 \\
45,4 \\
5 \%\end{array}$ & 0 & $\begin{array}{c}6 \\
2,02 \\
\%\end{array}$ & $\begin{array}{c}+6 \\
2,02 \\
\%\end{array}$ \\
\hline $\begin{array}{c}\text { Державний } \\
\text { контроль в } \\
\text { управлінні } \\
\text { діяльністю } \\
\text { закладів } \\
\text { дошкільної освіти } \\
\end{array}$ & $\begin{array}{c}53 \\
17,8 \\
5 \\
\%\end{array}$ & $\begin{array}{r}285 \\
95,9 \\
6 \%\end{array}$ & $\begin{array}{l}+205 \\
69,0 \\
2 \%\end{array}$ & $\begin{array}{l}103 \\
34,6 \\
8 \%\end{array}$ & 0 & 0 & $\begin{array}{l}141 \\
47,4 \\
7 \%\end{array}$ & $\begin{array}{c}7 \\
2,36 \\
\%\end{array}$ & $\begin{array}{l}-134 \\
45,1 \\
2 \%\end{array}$ & 0 & $\begin{array}{c}5 \\
1,68 \\
\%\end{array}$ & $\begin{array}{c}+5 \\
1,68 \\
\%\end{array}$ \\
\hline $\begin{array}{c}\text { Інституційний } \\
\text { аудит закладів } \\
\text { освіти }\end{array}$ & $\begin{array}{c}21 \\
7,07 \\
\%\end{array}$ & $\begin{array}{c}277 \\
93,2 \\
7 \%\end{array}$ & $\begin{array}{l}+256 \\
86,2 \\
0 \%\end{array}$ & $\begin{array}{l}229 \\
77,1 \\
0 \%\end{array}$ & 0 & 0 & $\begin{array}{c}47 \\
15,8 \\
2 \%\end{array}$ & $\begin{array}{c}9 \\
3,03 \\
\%\end{array}$ & $\begin{array}{l}-38 \\
12,7 \\
9 \%\end{array}$ & 0 & $\begin{array}{c}11 \\
3,70 \\
\%\end{array}$ & $\begin{array}{c}+11 \\
3,70 \\
\%\end{array}$ \\
\hline $\begin{array}{c}\text { Методи } \\
\text { державного } \\
\text { контролю в } \\
\text { управлінні } \\
\text { діяльністю 3ДО }\end{array}$ & $\begin{array}{c}17 \\
5,72 \\
\%\end{array}$ & $\begin{array}{l}283 \\
95,2 \\
9 \%\end{array}$ & $\begin{array}{l}+266 \\
89,5 \\
6 \%\end{array}$ & $\begin{array}{l}237 \\
79,8 \\
0 \%\end{array}$ & 0 & 0 & $\begin{array}{c}43 \\
14,4 \\
8 \%\end{array}$ & $\begin{array}{l}5 \\
1,68 \\
\%\end{array}$ & $\begin{array}{l}-38 \\
12,7 \\
9 \%\end{array}$ & 0 & $\begin{array}{c}9 \\
3,03 \\
\%\end{array}$ & $\begin{array}{c}+9 \\
3,03 \\
\%\end{array}$ \\
\hline $\begin{array}{c}\text { Положення про } \\
\text { атестацію } \\
\text { педагогічних } \\
\text { працівників } \\
\end{array}$ & $\begin{array}{l}101 \\
34,0 \\
1 \%\end{array}$ & $\begin{array}{l}284 \\
95,6 \\
2 \%\end{array}$ & $\begin{array}{c}+192 \\
64,6 \\
5 \%\end{array}$ & $\begin{array}{l}129 \\
43,4 \\
3 \%\end{array}$ & 0 & 0 & $\begin{array}{c}58 \\
19,5 \\
3 \%\end{array}$ & 0 & $\begin{array}{l}-58 \\
19,5 \\
3 \%\end{array}$ & $\begin{array}{c}9 \\
3,03 \\
\%\end{array}$ & $\begin{array}{c}13 \\
4,38 \\
\%\end{array}$ & $\begin{array}{c}+4 \\
1,35 \\
\%\end{array}$ \\
\hline
\end{tabular}

Наведені результати опитування свідчать про те, що найбільше труднощів студенти спеціальності 012 «Дошкільна освіта» освітнього ступеня «магістр» мають у розкритті таких питань: державний контролю в управлінні діяльністю закладів дошкільної освіти (майже 32,68 \% студентів не володіють інформацією 3 питання), інституційний аудит закладів освіти $(77,10$ \% опитаних потребують допомоги у вивченні даного питання). Недостатня поінформованість респондентів 3 досліджуваного питання зумовлена браком каналів поширення інформації та малочисельною кількістю дисциплін управлінського характеру. 
Вивчення отриманих даних після опрацювання дистанційного спецкурсу студентами спеціальності 012 «Дошкільна освіта» освітнього ступеня «магістр» дало можливість констатувати: у порівнянні 3 даними до опрацювання дистанційного спецкурсу, де інформацією про становлення та розвиток моніторингу якості освіти володіли 52,53\% респондентів, після опрацювання дистанційного спецкурсу кількість осіб, які достатньо володіють інформацією $з$ даного питання, збільшилась - 97,31 \% опитаних; окрім того, готовність поділитися матеріалом засвідчили 2,69 \%, коли до опрацювання дистанційного спецкурсу їх було всього 1,01\%. Загалом, до опрацювання дистанційного спецкурсу «Моніторинг якості освіти: державний контроль в управлінні діяльністю закладів дошкільної освіти» готовність поділитися матеріалом засвідчили 9,09 \% респондентів; інформація, яку ми отримали після опрацювання дистанційного спецкурсу, нас приємно здивувала, адже готовність поділитися матеріалом засвідчили 22,90 \% опитаних студентів.

За результатами опитування, магістранти потребують глибшого розкриття матеріалу стосовно питань моніторингу якості дошкільної освіти, державного контролю в управлінні діяльністю закладами дошкільної освіти, історіографії становлення державного контролю (друга половина XX - початок XXI століття). Розкриття зазначених питань дозволить магістрантам спеціальності 012 «Дошкільна освіта» зрозуміти проблеми сучасної теорії $\mathrm{i}$ практики управління дошкільною освітою України.

Вихователі, вихователі-методисти та директори закладів дошкільної освіти - слухачі курсів підвищення кваліфікації закладів післядипломної педагогічної освіти, відповідаючи на питання анкети, вказали на достатнє володіння інформацією про контроль та державний контроль у закладі дошкільної освіти, а 95,0 \% респондентів взагалі не володіють інформацією про етапи становлення державного контролю в управлінні діяльністю закладів дошкільної освіти в Україні. На нашу думку, низький рівень поінформованості опитаних 3 питання зумовлений недостатнім поширенням інформації про етапи становлення державного контролю в наукових джерелах, засобах масової інформації, малою кількістю організації наукових заходів та участі в таких заходах опитаних (круглі столи, семінари, конференції тощо).

Наступний блок запитань містив перелік тем з дистанційного спецкурсу «Моніторинг якості освіти: державний контроль в управлінні діяльністю закладів дошкільної освіти», де слухачі курсів підвищення кваліфікації закладів післядипломної педагогічної освіти мали вказати наскільки вони обізнані 3 тією чи іншою темою («достатньо володію інформацією», «не достатньо володію інформацією», «не володію інформацією взагалі», «можу поділитися матеріалами 3 даного питання) до опрацювання дистанційного спецкурсу та після його опрацювання. Результати даних щодо рівня обізнаності слухачів курсів підвищення кваліфікації закладів післядипломної педагогічної освіти до та після опрацювання дистанційного спецкурсу «Моніторинг якості дошкільної освіти» презентовані у зведеній таблиці 3.

Табличя 3.

\author{
Результати обізнаності слухачів курсів підвищення кваліфікації закладів \\ післядипломної педагогічної освіти з проблемою \\ державного контролю в управлінні діяльністю закладів дошкільної освіти України \\ (друга половина XX - початок XXI століття) \\ (за темами дистанційного спецкурсу)
}




\begin{tabular}{|c|c|c|c|c|c|c|c|c|c|c|c|c|}
\hline \multirow{2}{*}{ Питання } & \multicolumn{3}{|c|}{$\begin{array}{c}\text { Достатньо володію } \\
\text { інформацісю }\end{array}$} & \multicolumn{3}{|c|}{$\begin{array}{c}\text { Не володію } \\
\text { інформацісю } \\
\text { взагалі }\end{array}$} & \multicolumn{3}{|c|}{$\begin{array}{c}\text { Не достатньо } \\
\text { володію } \\
\text { інформацією }\end{array}$} & \multicolumn{3}{|c|}{$\begin{array}{c}\text { Готовий } \\
\text { поділитися } \\
\text { матеріалом }\end{array}$} \\
\hline & 울 & 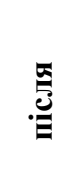 & 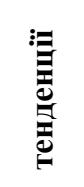 & 是 & $\stackrel{5}{\underline{e}}$ & 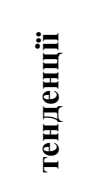 & 음 & 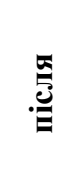 & 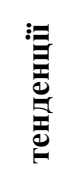 & 요 & 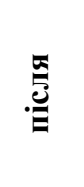 & 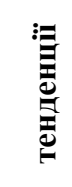 \\
\hline $\begin{array}{l}\text { Поняття про } \\
\text { якість світи }\end{array}$ & $\begin{array}{c}44 \\
97,7 \\
8 \% \\
\end{array}$ & $\begin{array}{c}45 \\
100 \\
\%\end{array}$ & $\begin{array}{c}+1 \\
2,22 \\
\%\end{array}$ & 0 & 0 & - & $\begin{array}{c}1 \\
2,22 \\
\%\end{array}$ & 0 & $\begin{array}{c}-1 \\
2,22 \\
\%\end{array}$ & $\begin{array}{c}12 \\
26,6 \\
7 \% \\
\end{array}$ & $\begin{array}{c}35 \\
77,7 \\
8 \% \\
\end{array}$ & $\begin{array}{l}+23 \\
51,1 \\
1 \%\end{array}$ \\
\hline $\begin{array}{c}\text { Становлення та } \\
\text { розвиток } \\
\text { моніторингу } \\
\text { якості освіти }\end{array}$ & $\begin{array}{c}5 \\
11,1 \\
1 \%\end{array}$ & $\begin{array}{c}39 \\
86,6 \\
7 \%\end{array}$ & $\begin{array}{l}+34 \\
75,5 \\
6 \%\end{array}$ & $\begin{array}{c}26 \\
57,7 \\
8 \%\end{array}$ & 0 & $\begin{array}{l}-26 \\
57,7 \\
8 \%\end{array}$ & $\begin{array}{c}14 \\
31,1 \\
1 \%\end{array}$ & $\begin{array}{c}6 \\
13,3 \\
3 \%\end{array}$ & $\begin{array}{l}-8 \\
17,7 \\
8 \%\end{array}$ & 0 & 0 & - \\
\hline $\begin{array}{c}\text { Організація } \\
\text { контролю в } \\
\text { закладі } \\
\text { дошкільної } \\
\text { освіти } \\
\end{array}$ & $\begin{array}{c}25 \\
55,5 \\
6 \%\end{array}$ & $\begin{array}{c}40 \\
88,8 \\
9 \%\end{array}$ & $\begin{array}{l}+15 \\
33,3 \\
3 \%\end{array}$ & $\begin{array}{c}2 \\
4,44 \\
\%\end{array}$ & 0 & $\begin{array}{c}-2 \\
4,44 \\
\%\end{array}$ & $\begin{array}{c}18 \\
40 \%\end{array}$ & $\begin{array}{c}5 \\
11,1 \\
1 \%\end{array}$ & $\begin{array}{c}13 \\
28,8 \\
9 \%\end{array}$ & $\begin{array}{c}24 \\
53,3 \\
3 \%\end{array}$ & $\begin{array}{c}38 \\
84,4 \\
4 \%\end{array}$ & $\begin{array}{l}+14 \\
31,1 \\
1 \%\end{array}$ \\
\hline $\begin{array}{c}\text { Державний } \\
\text { контроль в } \\
\text { управлінні } \\
\text { діяльністю } \\
\text { закладів } \\
\text { дошкільної } \\
\text { освіти } \\
\end{array}$ & $\begin{array}{c}27 \\
60 \%\end{array}$ & $\begin{array}{c}43 \\
95,5 \\
6 \%\end{array}$ & $\begin{array}{l}+16 \\
35,5 \\
6 \%\end{array}$ & $\begin{array}{c}2 \\
4,44 \\
\%\end{array}$ & 0 & $\begin{array}{c}-2 \\
4,44 \\
\%\end{array}$ & $\begin{array}{c}16 \\
35,5 \\
6 \%\end{array}$ & 0 & $\begin{array}{l}-16 \\
35,5 \\
6 \%\end{array}$ & $\begin{array}{c}24 \\
53,3 \\
3 \%\end{array}$ & $\begin{array}{c}27 \\
60 \%\end{array}$ & $\begin{array}{c}+3 \\
6,67 \\
\%\end{array}$ \\
\hline $\begin{array}{c}\text { Інституційний } \\
\text { аудит закладів } \\
\text { освіти }\end{array}$ & $\begin{array}{c}26 \\
57,7 \\
8 \%\end{array}$ & $\begin{array}{c}39 \\
86,6 \\
7 \%\end{array}$ & $\begin{array}{l}+13 \\
28,8 \\
9 \%\end{array}$ & $\begin{array}{c}2 \\
4,44 \\
\%\end{array}$ & 0 & $\begin{array}{c}-2 \\
4,44 \\
\%\end{array}$ & $\begin{array}{c}17 \\
37,7 \\
8 \%\end{array}$ & $\begin{array}{c}6 \\
13,3 \\
3 \%\end{array}$ & $\begin{array}{l}-11 \\
24,4 \\
4 \%\end{array}$ & 0 & 0 & - \\
\hline $\begin{array}{c}\text { Методи } \\
\text { державного } \\
\text { контролю в } \\
\text { управлінні } \\
\text { діяльністю 3ДО }\end{array}$ & $\begin{array}{c}24 \\
53,3 \\
3 \%\end{array}$ & $\begin{array}{c}37 \\
82,2 \\
2 \%\end{array}$ & $\begin{array}{l}+13 \\
28,8 \\
9 \%\end{array}$ & $\begin{array}{c}2 \\
4,44 \\
\%\end{array}$ & 0 & $\begin{array}{c}-2 \\
4,44 \\
\%\end{array}$ & $\begin{array}{c}19 \\
42,2 \\
2 \%\end{array}$ & $\begin{array}{c}8 \\
17,7 \\
8 \%\end{array}$ & $\begin{array}{l}-11 \\
24,4 \\
4 \%\end{array}$ & 0 & 0 & - \\
\hline $\begin{array}{c}\text { Положення про } \\
\text { атестацію } \\
\text { педагогічних } \\
\text { працівників }\end{array}$ & $\begin{array}{c}44 \\
97,7 \\
8 \%\end{array}$ & $\begin{array}{c}45 \\
100 \\
\%\end{array}$ & $\begin{array}{c}+1 \\
2,22 \\
\%\end{array}$ & 0 & 0 & - & 0 & 0 & - & $\begin{array}{c}27 \\
60 \%\end{array}$ & $\begin{array}{c}41 \\
91,1 \\
1 \%\end{array}$ & $\begin{array}{r}+14 \\
31,1 \\
1 \%\end{array}$ \\
\hline
\end{tabular}

Аналіз отриманих результатів після опрацювання дистанційного спецкурсу слухачами курсів підвищення кваліфікації закладів післядипломної педагогічної освіти дав можливість встановити, що в порівнянні $з$ даними до опрацювання дистанційного спецкурсу (26,67 \%) готовність поділитися матеріалом з питання про якість освіти засвідчили 77,78 \% опитаних; $86,67 \%$ респондентів вказують на достатне оволодіння інформацією про становлення та розвиток моніторингу якості освіти; 95,56 \% слухачів курсів підвищення кваліфікації закладів 
післядипломної педагогічної освіти достатньо оволоділи питанням про державний контроль в управлінні діяльністю закладів дошкільної освіти. Загалом збільшилася кількість респондентів, які готові поділитися матеріалом з тем.

Відтак пропонований дистанційний спецкурс «Моніторинг якості освіти: державний контроль в управлінні діяльністю закладів дошкільної освіти» забезпечив опанування слухачами закладів післядипломної педагогічної освіти інформацією про актуальні питання моніторингу якості освіти та управління дошкільною освітою зокрема.

Після завершення вивчення спецкурсу студентам та слухачам було запропоновано пройти підсумковий тест-контроль, який розміщено в мережі Інтернет 3 допомогою онлайн форми Google (респондентам було відправлено форму на електронну пошту 3 проханням заповнити іiі). Відтак студенти та слухачі мали змогу перевірити дієвість самостійного опрацювання дистанційного спецкурсу «Моніторинг якості освіти: державний контроль в управлінні діяльністю закладів дошкільної освіти», а ми перевірити результативність упровадження спецкурсу в освітній процес.

Після опрацювання результатів підсумкового тест-контролю ми з'ясували, що пропонований дистанційний спецкурс «Моніторинг якості освіти: державний контроль в управлінні діяльністю закладів дошкільної освіти» забезпечив опанування студентами та слухачами закладів післядипломної педагогічної освіти відповідної теорії та сприяв підвищенню рівня пізнавальних інтересів 3 питань державного контролю в управлінні діяльністю дошкільних закладів України (друга половина XX - початок XXI століття).

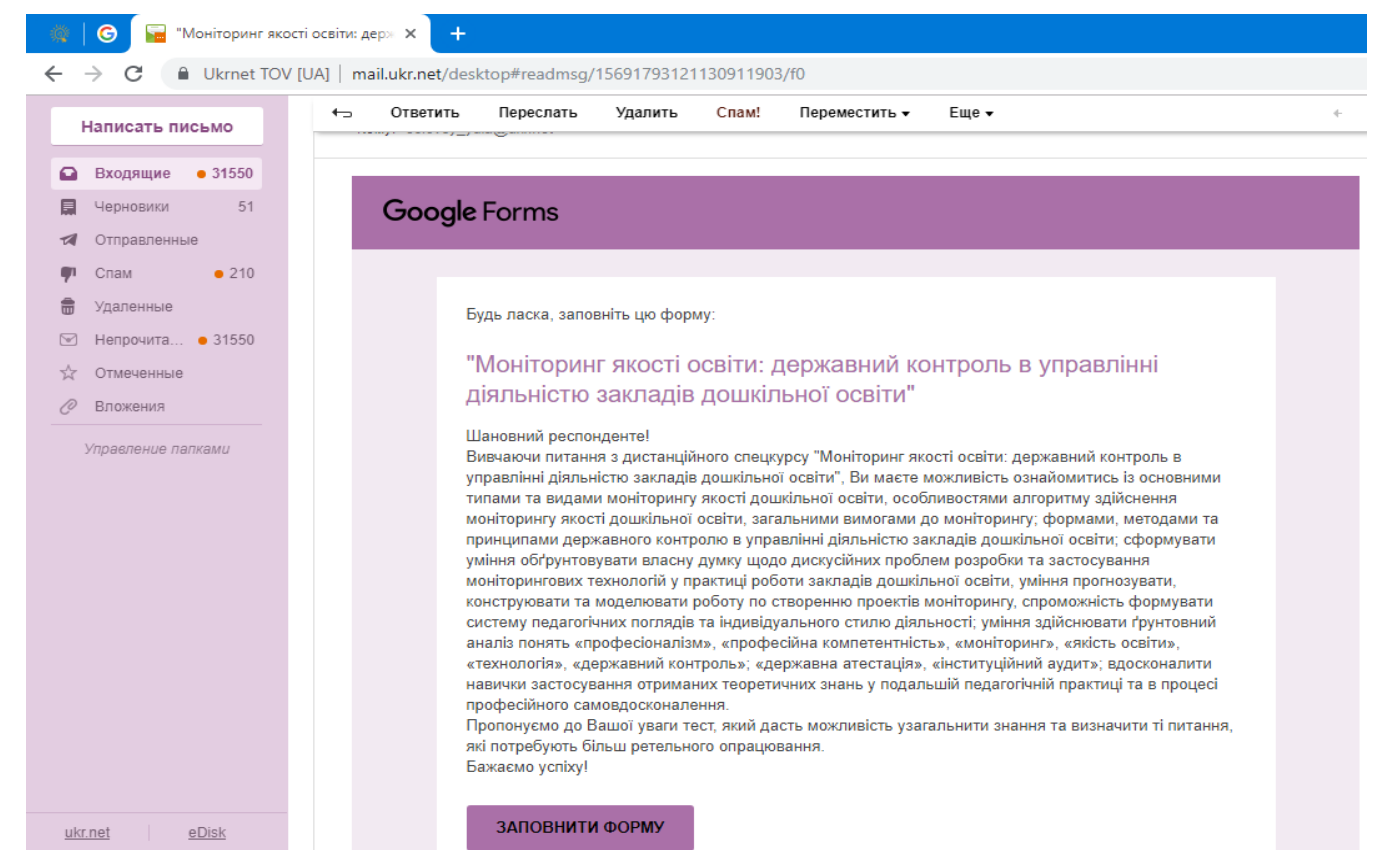

Рис. 5. Тест для респондентів, які опанували дистаниійний спецкурс «Моніторинг якості освіти: державний контроль в управлінні діяльністю закладів дошкільної освіти» 


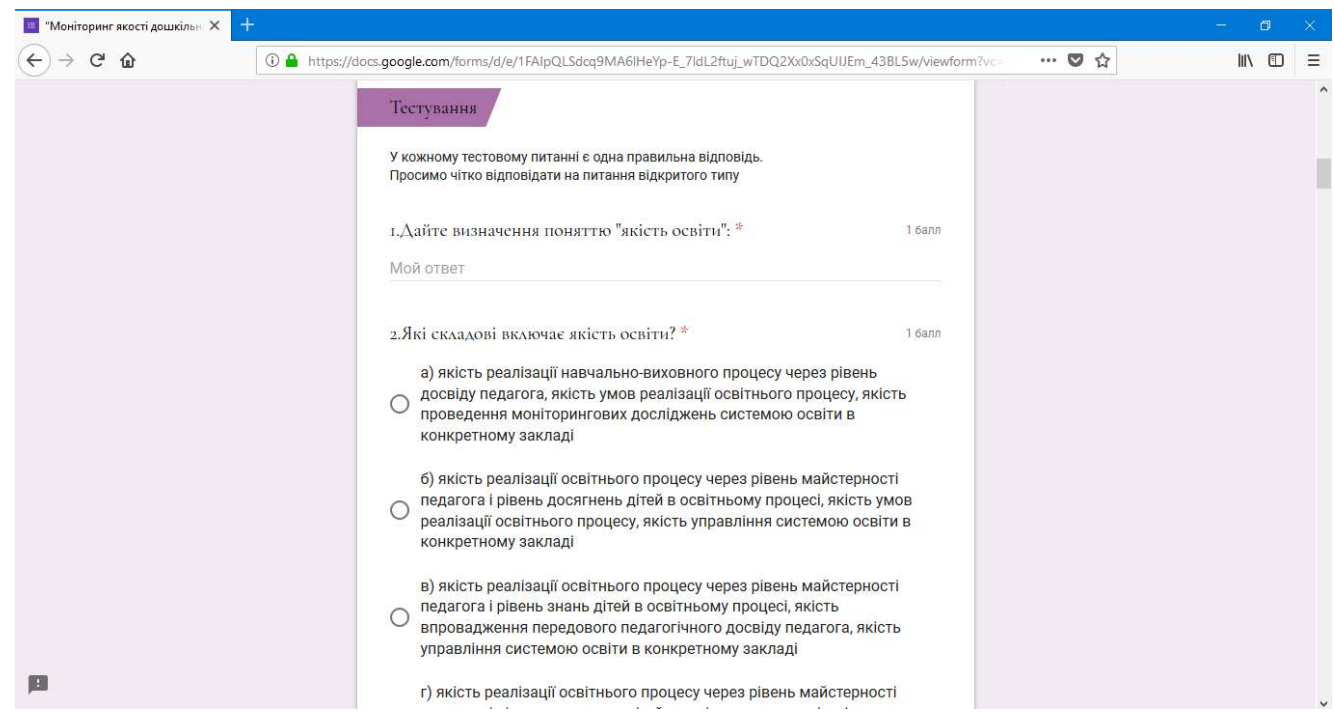

Рис. 6. Підсумковий тест до дистаниійного спеикурсу «Моніторинг якості освіти: державний контроль в управлінні діяльністю закладів дошкільної освіти»

\section{4. ВИСНОВКИ І ПЕРСПЕКТИВИ ПОДАЛЬШИХ ДОСЛІДЖЕНЬ}

На основі проведеного аналізу наукової й методичної літератури, нормативної бази дистанційного навчання, власного педагогічного досвіду доведено необхідність розв'язання проблеми впровадження дистанційного спецкурсу «Моніторинг якості освіти: державний контроль в управлінні діяльністю закладів дошкільної освіти» для студентів закладів вищої освіти та слухачів курсів підвищення кваліфікації, котра виникла у зв'язку 3 їх необізнаністю в питаннях державного контролю та управління закладами дошкільної освіти. Результати отриманих даних дають можливість зробити висновок, що пропонований нами для впровадження в освітній процес закладів вищої та післядипломної освіти дистанційний спецкурс засвідчив неабиякі можливості використання сучасних IКТ та педагогічних інновацій, креативне поєднання різноманітних форм, методів та засобів навчання для вирішення фахових завдань та поглиблення аналізу проблем дошкільної освіти засобами ІК-технологій. Опрацьовуючи отримані результати, ми дійшли висновку, що студенти закладів вищої освіти та слухачі курсів підвищення кваліфікації покращили свої знання з теорії управління дошкільною освітою та здобули знання, які необхідні їм у практичній професійній діяльності.

Проведене нами пілотне дослідження дало змогу виявити недостатній рівень обізнаності з інформацією про державний контроль в управлінні діяльністю закладів дошкільної освіти України, моніторингу якості дошкільної освіти, історіографією становлення державного контролю в управлінні діяльністю закладами дошкільної освіти України (друга половина XX початок XXI століття), а також усвідомлення студентами-бакалаврами, магістрами та слухачами курсів підвищення кваліфікації актуальності цих тем у сучасний період.

Проведене дослідження не вичерпує всіх аспектів проблеми, що вивчається. Наступним етапом дослідження буде вивчення прогресивних надбань зарубіжної системи управління системою дошкільної освіти, використання та впровадження цього інноваційного досвіду в систему управління освітою України; розробка сучасних дидактичних засобів, форм 
організації самостійної роботи студентів та використання потенційних можливостей ІКТ для впровадження дієвих засобів навчання на освітній онлайн платформі.

\section{СПИСОК ВИКОРИСТАНИХ ДЖЕРЕЛ}

[1] Наказ Міністерства освіти і науки України Про затвердження примірного статуту дошкільного навчального закладу, Інформаиійний збірник, № 12, с. 12-20, 2003

[2] Л. С. Пісоцька, Соціально-педагогічні умови управління розвитком дошкільної освіти в регіоні : автореф. дис. на здобуття наук. ступеня канд. пед. наук, Київ, 20 с., 2004.

[3] I. L. Pokrovska, Formation of media competence of students of humanitarian faculties during the study of specialized disciplines, Information Technologies and Learning Tools, Vol 71, no 3, p. 215, 2019.

[4] О.О.Михальчук, І. О. Ніколаєску, Н. М. Степанова, Особливості професійно-педагогічної самореалізації викладачів засобами ІКТ у міжкурсовий період, Інформаційні технології $і$ засоби навчання, № 5, с. 251, 2018.

[5] В. С. Божинський, Державна атестація навчального закладу : нормативно-правові документи, Практика управління закладом освіти, № 2, с. 41, 2016.

[6] В. В. Гончарук, Шляхи розвитку сучасного управління освітою у регіоні, Вісник Житомирського державного університету імені Івана Франка, № 3, с. 186, 2014.

[7] Д. І. Дзвінчук Розвиток освіти як суспільної цінності : історико-філософський дискурс, Розвиток сучасноі освіти : освітологічні наголоси : наук. праці за матер. першої Всеукр. наук.-практ.конф, Київ, Київ.ун-т ім. Б. Грінченка, с. 110, 2011.

[8] Г. В. Касьянов, Освітня система України 1990 - 2014 : аналітичний огляд, Київ Таксон, 52 с., 2015.

[9] С. В. Крисюк, Державне управління освітою, Навчальний посібник для слухачів, асп., докторантів спец. «Державне управління освітою», Київ, НАДУ, 220 с., 2009.

[10] А. А. Гуз, Система контроля в дошкольном учреждении, Учебно-методическое пособие, Минск, 178 с., 2010.

[11] Т. М. Десятов, О. М. Коберник, Б. Л. Тевлін, Н. М. Чепурна, Наука управління загальноосвітнім навчальним закладом, Навчальний посібник, Харків, Основа, 240 с, 2003.

[12] 3. М. Канівець, В. П. Шпак, Організаиія і методика інспектування шкіл у системі управління освітою в Україні другої половини ХХ ст., Полтава ПОІППО, 189 с., 2014.

[13] Т. М. Куценко, Організаційно-педагогічні умови ефективності державного контролю за діяльністю початкової школи : дис. на здобуття наук. ступеня канд. пед. наук : 13.00.06, Київ, 334 с., 2015.

[14] А. Г. Панченко, Державний контроль в системі управління загальноосвітніми навчальними закладами: автореф. дис. на здобуття наук. ступеня канд. держ. упр, Запоріжжя, 23 с., 2010.

[15] Л. С. Пісоцька, Аналіз результативності управління розвитком дошкільної освіти в Україні у 60-80-ті pp. ХХ століття, Педагогіка формування творчої особистості у вищій $і$ загальноосвітній школах, № 28, с. 37, 2013.

[16] О. Г. Косенчук, Н. В. Бахмут, Модель інформаційно-комунікаційного забезпечення управління якістю дошкільної освіти. Інформачійні технології $і$ засоби навчання, №1, том 69, 246-257, 2019.

[17] Т. И. Пуденко, Т. Н. Богуславская, К вопросу о критериях оценки эффективности деятельности дошкольных образовательных организаций. Управление образованием: теория и практика, № 2, с. 13, 2015.

[18] В. В. Грядуща, М. П. Шевченко, Використання цифрових технологій під час управління закладом дошкільної освіти. Інноваиійна педагогіка: теорія і методика управління освітою, № 21, том 3, с. 164-168, 2020.

[19] I. М. Крутій, Г. М. Дмитренко, Технологія тайм-менеджменту в управлінні сучасним дошкільним навчальним закладом. Матеріали V Міжнародного фестивалю педагогічних інноваиій, Черкаси: ЧОПОПП, 19-20 вересня, с. 35-38, 2013.

[20] М. М. Поташник, Управление качеством образования, Практико ориентированная монография и методическое пособие, Москва Педагогическое общество, 448 с., 2000.

[21] Ю. Г. Новгородська, Особливості формування у майбутніх керівників дошкільних навчальних закладів управлінських умінь. Наукові записки НДУ ім. М. Гоголя: Психолого-педагогічні науки, № 1, с. 195-199, 2016.

[22] А. В. Яцинік, Самоменеджмент керівників дошкільних навчальних закладів у системі післядипломної освіти. Витоки педагогічної майстерності, № 16, с. 313-319, 2015. 
[23] Закон України «Про освіту» № 1060-XII, зі змінами від 11 червня 2008 р. BВР, № 27, с. 49, 2008.

[24] О. Л. Кононко, А. С. Зайченко, Діагностика сектору дошкільної освіти в Україні : звіт за результатами комплексного дослідження, Київ Відродження, 145 с., 2013.

[25] С. С. Аверинцев, Э. А. Араб-Оглы, Л. Ф. Ильчев, Философский энииклопедический словарь, Москва Сов. Энциклопедия, 815 с., 1989.

[26] Ю. О. Соловей, Стан розроблення проблеми державного контролю за діяльністю дошкільних навчальних закладів у вітчизняній теорії та практиці управління освітою, Вісник Черкаського університету. Серія «Педагогічні науки», № 11, с. 110, 2017.

[27] И. В. Житко, Планирование работы дошкольного учреждения, Пособие для педагогов дошк. учреждений, Минск Университетское, 184 с., 2001.

[28] Ю. О. Соловей, Принципи державного контролю за діяльністю дошкільних навчальних закладів як основної функції управління у галузі дошкільної освіти, International research and practice conference «Modern methods, innovations and operational experience in the field of psychology and pedagogics»: Conference proceedings, Lublin: Izdevnieciba «Baltija Publishing», October 20-21, p. 132, 2017.

[29] Т. Маматова, Трактування поняття «державний контроль» у сучасному законодавстві України та його уточнення, Вісник державної служби України. № 1, с. 23-26, 2004.

[30] Кабінет Міністрів України «Положення про дошкільний навчальний заклад № 305 від 12 березня 2003 р.», Все для вчителя, № 25-27, с. 17-18, 2011.

[31] Ю. О. Соловей, Історіографія становлення державного контролю за діяльністю закладів дошкільної освіти в Україні (друга половина XX - початок XXI століття), Science and Education a New Dimension. Pedagogy and Psychology Budapest, № 180, p. 51-52, 2018.

[32] Наказ МОН України від 09.01.2019 № 17 «Про затвердження Порядку проведення інституційного аудиту закладів загальної середньої освіти». [Електронний ресурс]. Доступно: https://zakon.rada.gov.ua/laws/show/z0250-19\#Text

[33] Наказ МОН України від 16.01.2020 № 54 «Про затвердження порядку проведення моніторингу якості освіти». [Електронний ресурс]. Доступно: https://zakon.rada.gov.ua/laws/show/z0154-20\#Text

Матеріал надійшов до редакиії 16.02.2020 p.

\title{
ВНЕДРЕНИЕ ДИСТАНЦИОННОГО СПЕЦКУРСА «МОНИТОРИНГ КАЧЕСТВА ОБРАЗОВАНИЯ: ГОСУДАРСТВЕННЫЙ КОНТРОЛЬ В УПРАВЛЕНИИ ДЕЯТЕЛЬНОСТИ УЧРЕЖДЕНИЙ ДОШКОЛЬНОГО ОБРАЗОВАНИЯ»
}

\author{
Николаеску Инна Александровна \\ доктор педагогических наук, доцент кафедры дошкольного образования \\ Черкасский национальный университет імени Богдана Хмельницкого, г. Черкассы, Украина \\ ORCID 0000-0002-9928-9291X \\ nikolaesky@ukr.net \\ Степанова Наталия Михайловна \\ кандидат философских наук, доцент кафедры профессионального развития педагогов \\ КОУ «Черкасский областной институт последипломного образования педагогических работников \\ Черкасского областного совета», г. Черкассы, Украина \\ ORCID 0000-0002-6842-629X \\ stepanova76@ukr.net
}

\section{Соловей Юлия Александровна}

аспирантка кафедры дошкольного образования

Черкасский национальный университет имени Богдана Хмельницкого, г. Черкассы, Украина

ORCID 0000-0003-4778-7640

solovey_yula@ukr.net 


\begin{abstract}
Аннотация. В статье представлены результаты пилотного исследования по формированию компетентности студентов учреждений высшего образования и слушателей курсов повышения квалификации при изучении вопросов государственного контроля в управлении деятельностью учреждений дошкольного образования в Украине (вторая половина XX - начало XXI века) путем внедрения в образовательный процесс дистанционного спецкурса «Мониторинг качества образования: государственный контроль в управлении деятельностью учреждений дошкольного образования». Обоснована актуальность создания и внедрения в образовательный процес высших учебных заведений и учреждений последипломного педагогического образования дистанционного спецкурса. Выделены этапы становления и развития государственного контроля в управлении деятельностью учреждений дошкольного образования Украины. Учитывая новейшие научные исследования по этому вопросу и собственные практические наработки, представлен тематический план спецкурса. Акцентировано, что результативность внедрения и использования в образовательной практике высших учебных заведений и учреждений последипломного педагогического образования дистанционного спецкурса зависит от уровня профессионального образования и ИК-компетентности студентов и слушателей. Обосновано суждения о том, что в основе внедрения дистанционного спецкурса лежит принцип начальных знаний, который предполагает усвоение студентами и слушателями опорных знаний по основам компьютерной грамотности, возможность доступа к сети Интернет и необходимое техническое обеспечение. По результатам выходного диагностирования студентов выяснено, что внедрение дистанционного спецкурса способствует решению профессиональных задач, углублению знаний по теории управления дошкольным образованием, является базовой основой практической профессиональной деятельности, а в дальнейшем будет способствовать решению проблем дошкольного образования. Определены направления дальнейшего исследования: изучение лучших достижений зарубежной системы управления системой дошкольного образования с целью внедрения лучшего опыта в систему управления образованием Украины, использование учебно-методического пособия во время предлагаемого дистанционного спецкурса и размещение материалов на образовательный онлайн-платформе.
\end{abstract}

Ключевые слова: дошкольное образование; управление; контроль; мониторинг; государственный контроль; качество образования; информационно-коммуникационные технологии; профессиональная осведомленность; дистанционный спецкурс.

\title{
IMPLEMENTATION OF DISTANCE LEARNING SPECIAL COURSE "MONITORING OF EDUCATION QUALITY: STATE CONTROL IN MANAGEMENT OF PRESCHOOL EDUCATION INSTITUTIONS"
}

\author{
Inna O. Nikolaesku \\ Bohdan Khmelnytsky Cherkasy National University, Cherkasy, Ukraine \\ ORCID ID 0000-0002-9928-9291X \\ nikolaesky@ukr.net \\ Nataliia M. Stepanova \\ Cherkasy, Ukraine \\ ORCID ID 0000-0002-6842-629X \\ stepanova76@ukr.net \\ Yuliia O. Solovei \\ PhD student of Preschool Education Department \\ Bohdan Khmelnytsky Cherkasy National University, Cherkasy, Ukraine \\ ORCID ID 0000-0003-4778-7640 \\ solovey_yula@ukr.net
}

Doctor of Pedagogical Sciences, Associate Professor at the Department of Preschool Education

$\mathrm{PhD}$ of Psychology Sciences, Associate Professor at the Department of Teacher's Professional Development Municipal Educational Institution of Cherkasy Regional Council «Cherkasy In-service Teacher Training Institute», 


\begin{abstract}
The article focuses on the results of the pilot research concerning competence formation of higher school and postgraduate courses students while studying the program on state control issues in management of preschool education institutions in Ukraine (the latter half of the XX - the beginning of the XXI centuries) by implementing "Monitoring of education quality: state control in management of preschool education institutions" distance learning special course into the educational process. The topicality of creation and introduction of distance learning special course "Monitoring of education quality: state control in management of preschool education institutions" into the educational process of higher schools and institutions of postgraduate pedagogical education is substantiated. The stages of formation and development of state control in the management of preschool education institutions in Ukraine are highlighted. The indicative thematic plan of the special course is presented based on the analysis of scientists' works, educational and methodical textbooks, and the authors' own experience. The efficiency of implementation and use of the distance learning special course in the educational practice of higher schools and postgraduate pedagogical institutions depends on the level of professional education as well as students' IT-competence. The judgement on dependence of implementing distance learning special course on the principle of initial knowledge that shows students' mastering of basic knowledge on computer literacy, on availability of Internet access and necessary technical support, is substantiated. According to the results of the initial students' assessment, it was found out that the introduction of the special distance course helps to solve professional problems, deepen knowledge of the theory of preschool education management. The course is the basis for practical professional activity, and can promote further development of preschool education. The areas of follow-up research are identified as: study of the best achievements of foreign preschool education management system in order to use and implement the best practices in the education management system of Ukraine, implementation of the proposed special course manual and placement of materials on the educational online platform.

Keywords: preschool education; management; control; monitoring; state control; education quality; information and communication technologies; professional awareness; distance learning special course.
\end{abstract}

\title{
REFERENCES (TRANSLATED AND TRANSLITERATED)
}

[1] Order of the Ministry of Education and Science of Ukraine, "On approval of the exemplary charter of a preschool educational institution, Informatsiinyi zbirnyk,” № 12, pp. 12-20, 2003 (in Ukrainian)

[2] L. S. Pisotska, Socio-pedagogical conditions for managing the development of preschool education in the region: avtoref. dys. na zdobuttia nauk. stupenia kand. ped. nauk, Kyiv, 20 p., 2004. (in Ukrainian)

[3] I. L. Pokrovska, "Formation of media competence of students of humanitarian faculties during the study of specialized disciplines," Information Technologies and Learning Tools, vol 71, no 3, p. 215, 2019. (in English)

[4] O. O. Mykhalchuk, I. O. Nikolaiesku, H. M. Stepanova, "The peculiarities of teachers' professional and pedagogical self-realization by means of information and communication technologies in intercourse time," Information Technologies and Learning Tools, № 5, p. 251, 2018. (in Ukrainian)

[5] V.S. Bozhynskyi, "State attestation of the educational institution: regulatory legal documents," Praktyka upravlinnia zakladom osvity, № 2, p. 41, 2016. (in Ukrainian)

[6] V. V. Honcharuk, "Ways to develop modern education management in the region," Visnyk Zhytomyrskoho derzhavnoho universytetu imeni Ivana Franka, № 3, p. 186, 2014. (in Ukrainian)

[7] D. I. Dzvinchuk, "The development of education as a social value: a historical and philosophical discourse," Rozvytok suchasnoi osvity: osvitolohichni naholosy: nauk. pratsi za mater. pershoi Vseukr. nauk.-prakt.konf, Kyiv, Kyiv.un-t im. B. Hrinchenka, p. 110, 2011. (in Ukrainian)

[8] H. V. Kasianov, “Ukraine's education system 1990 - 2014: an analytical review,” Kyiv Takson, 52 p., 2015. (in Ukrainian)

[9] S. V. Krysiuk, "Public Administration of Education,” Navchalnyi posibnyk dlia slukhachiv, asp., doktorantiv spets. «Derzhavne upravlinnia osvitoiu», Kyiv, NADU, 220 p., 2009. (in Ukrainian)

[10] A. A. Huz, "Control system in a preschool institution," Uchebno-metodycheskoe posobye, Mynsk, 178 p., 2010. (in Russian)

[11] T. M. Desiatov, O. M. Kobernyk, B. L. Tevlin, N. M. Chepurna, "The science of managing a general educational institution," Navchalnyi posibnyk, Kharkiv, Osnova, 240 p, 2003. (in Ukrainian) 
[12] Z. M. Kanivets, V.P. Shpak, "Organization and methodology of inspecting schools in the system of education management in Ukraine in the second half of XX century," Poltava POIPPO, 189 p., 2014. (in Ukrainian)

[13] T. M. Kutsenko, Organizational and pedagogical conditions for the effectiveness of state control over primary school activity: dys. na zdobuttia nauk. stupenia kand. ped. nauk: 13.00.06, Kyiv, 334 p., 2015. (in Ukrainian)

[14] A. H. Panchenko, State control in the system of management of general educational institutions: avtoref. dys. na zdobuttia nauk. stupenia kand. derzh. upr, Zaporizhzhia, 23 p., 2010. (in Ukrainian)

[15] L. S. Pisotska, "Analysis of the Effectiveness of Preschool Education Development in Ukraine in the 60-80's of the XX Century," Pedahohika formuvannia tvorchoi osobystosti u vyshchii $i$ zahalnoosvitnii shkolakh, № 28 , p. 37 , 2013. (in Ukrainian)

[16] O. G. Kosenchuk, N. V. Bakhmut, "Model of information and communication support of quality management of preschool education." Information Technologies and Learning Tools, vol. 69, no.1, pp 246-257, 2019. (in Ukrainian)

[17] T. I. Pudenko, T. N. Boguslavskaya, "On the question of criteria for evaluating the effectiveness of preschool educational organizations." Education management: theory and practice, no. 2, p. 13, 2015.(in Russian)

[18] V. V. Hryadushcha, M. P. Shevchenko, "The use of digital technologies in the management of preschool education." Innovative pedagogy: theory and methods of education management, vol. 3, no 21, pp. 164-168, 2020. (in Ukrainian)

[19] I. M. Krutiy, G. M. Dmitrenko, "Technology of time management in the management of a modern preschool educational institution." Materials of the V International Festival of Pedagogical Innovations, Cherkasy: CHOPOPP, September 19-20, pp. 35-38, 2013. (in Ukrainian)

[20] M. M. Potashnyk, Education quality management, Praktyko-oryentyrovannaia monohrafyia y metodycheskoe posobye, Moskva Pedahohycheskoe obshchestvo, 448 p., 2000.(in Russian)

[21] Yu. G. Novgorodskaya, "Peculiarities of formation of managerial skills in future heads of preschool educational institutions." Scientific notes of NDU named after M. Gogol: Psychological and pedagogical sciences, № 1, pp. 195-199, 2016. (in Ukrainian)

[22] A. V. Yatsynik, "Self-management of heads of preschool educational institutions in the system of postgraduate education." Origins of pedagogical skill, no. 16, pp. 313-319, 2015. (in Ukrainian)

[23] Law of Ukrane «On Education» № 1060-XII, zi zminamy vid 11 chervnia 2008 r. VVR, № 27, p. 49, 2008. (in Ukrainian)

[24] O. L. Kononko, A. S. Zaichenko, "Diagnosis of the preschool education sector in Ukraine:" a report on the results of a comprehensive study, Kyiv Vidrodzhennia, 145 p., 2013. (in Ukrainian)

[25] S. S. Averyntsev, E. A. Arab-Ohlu, L. F. Ylchev, Encyclopedic Dictionary of Philosophy, Moskva Sov. Эntsyklopedyia, 815 p., 1989. (in Russian)

[26] Yu. O. Solovei, "State of development of the problem of state control over the activity of preschool educational institutions in the national theory and practice of educational management," Visnyk Cherkaskoho universytetu. Seriia «Pedahohichni nauky», no. 11, p. 110, 2017. (in Ukrainian)

[27] Y. V. Zhytko, "Planning the work of a preschool institution," Posobye dlia pedahohov doshk. uchrezhdenyi, Mynsk Unyversytetskoe, 184 p., 2001.(in Russian)

[28] Yu. O. Solovei, "Principles of state control over activity of preschool educational institutions as the main function of management in the field of preschool education," International research and practice conference "Modern methods, innovations and operational experience in the field of psychology and pedagogics»: Conference proceedings, Lublin: Izdevnieciba «Baltija Publishing», October 20-21, p. 132, 2017. (in Ukrainian)

[29] T. Mamatova, "Interpretation of the concept of "state control" in the current legislation of Ukraine and its clarification," Visnyk derzhavnoi sluzhby Ukrainy. no. 1, pp. 23-26, 2004. (in Ukrainian)

[30] Cabinet of Ministers of Ukraine "Regulations on preschool education № 305 from March 12, 2003." Vse dlia vchytelia, no. 25-27, pp. 17-18, 2011. (in Ukrainian)

[31] Yu. O. Solovei, "Historiography of the formation of state control over the activity of preschool educational institutions in Ukraine (the second half of the XX - beginning of the XXI century)," Science and Education a New Dimension. Pedagogy and Psychology Budapest, no. 180, pp. 51-52, 2018. (in Ukrainian)

[32] Order of the Ministry of Education and Science of Ukraine dated 09.01.2019 № 17 "On approval of the Procedure for conducting an institutional audit of general secondary education institutions." [Online]. Available: https://zakon.rada.gov.ua/laws/show/z0250-19\#Text (in Ukrainian)

[33] Order of the Ministry of Education and Science of Ukraine dated 16.01.2020 № 54 "On approval of the procedure for monitoring the quality of education." [Online]. Available: https://zakon.rada.gov.ua/laws/show/z0154-20\#Text (in Ukrainian).

\section{(cc) BY-NC-SA}

This work is licensed under Creative Commons Attribution-NonCommercial-ShareAlike 4.0 International License. 